\begin{tabular}{|c|c|}
\hline Title & A nion Conduction in Solid Electrolytes Probed by W ater Transport Measurement \\
\hline Author(s) & T akahashi, Hiroki; T akeguchi, T atsuy a; Y amanaka, Toshiro; U eda, W ataru \\
\hline Citation & $\begin{array}{l}\text { ECS Transactions, } 28(8), 83-86 \\
\text { https://doi.org/10.1149/1.3490685 }\end{array}$ \\
\hline Issue Date & 2010 \\
\hline Doc URL & http:/hdl.handle.net/2115/48158 \\
\hline Rights & $\begin{array}{l}\text { () The Electrochemical Society, Inc. 2010. All rights reserved. Except as provided under U.S. copyright law, this work } \\
\text { may not be reproduced, resold, distributed, or modified without the express permission of The Electrochemical Society } \\
\text { (ECS). The archival version of this work was published in ECS Trans., 28(8), pp.83-86. }\end{array}$ \\
\hline Type & article \\
\hline File Information & ECSt28-8_83-86.pdf \\
\hline
\end{tabular}

Instructions for use 


\title{
Anion Conduction in Solid Electrolytes Probed by Water Transport Measurement
}

\author{
H. Takahashi, T. Takeguchi, T. Yamanaka, and W. Ueda \\ Catalysis Research Center, Hokkaido University, Sapporo 001-0021, Japan
}

The application of inorganic materials as electrolyte of alkaline fuel cell is an important task to achieve noble-metal-free and hightemperature-resistant fuel cells. In the present study, water transport during ion conduction through solid electrolyte was measured to seek inorganic materials with anion conduction. We discovered the anion conduction in layered oxide $\mathrm{NaCo}_{2} \mathrm{O}_{4}$. Although $\mathrm{LiCoO}_{2}$ has the similar layered structure to $\mathrm{NaCo}_{2} \mathrm{O}_{4}$, this oxide showed cation conduction.

\section{Introduction}

Fuel cells have been investigated extensively as an alternative power source for solving energy/environmental problem. By using fuel cells, it is possible to extract electric energy with high efficiency through the production of $\mathrm{H}_{2} \mathrm{O}$ from $\mathrm{H}_{2}$ and $\mathrm{O}_{2}$ with clean exhaust gas. Despite over decades of intensive research, the high costs of fuel cells still inhibits commercialization. Alkaline fuel cells (AFCs) appear to be the most promising technology on a cost basis. The reasons for the increasing interest in such fuel cells are as follow. ${ }^{1}$ First, it is possible to use non-precious metals as cathode catalyst because the electro kinetics of oxygen reduction reaction at the cathode in an alkaline media is much higher than that in an acid media. Second, Ni, Co and some transition metals can be used as anode catalyst since the operation condition is alkaline. Recently some researchers reported AFC using anion exchange membrane as electrolyte, ${ }^{2-4}$ which is easily-handled because the electrolyte is solid. However, in this case, it is difficult to operate at higher temperatures than $60^{\circ} \mathrm{C}$. Therefore, inorganic electrolytes with anion conduction are strongly required to achieve noble-metal free and high-temperatureresistant AFC.

The aim of this study is to determine the charge carrier in inorganic solid to seek suitable electrolyte for AFC. The charge carriers in layered oxide $\mathrm{NaCo}_{2} \mathrm{O}_{4}$ and $\mathrm{LiCoO}_{2}$ are reported.

\section{Experimental}

\section{Preparation of $\mathrm{NaCO}_{2} \underline{\mathrm{O}}_{4}$ and $\mathrm{LiCoO}_{2}$}

$\mathrm{NaCo}_{2} \mathrm{O}_{4}$ was prepared by dry-up method. $\mathrm{CH}_{3} \mathrm{COONa}$ and $\left(\mathrm{CH}_{3} \mathrm{COO}\right)_{2} \mathrm{Co} \cdot 4 \mathrm{H}_{2} \mathrm{O}$ (purchased from Wako Pure Chemical Industry, Ltd.) were dissolved in distilled water. This solution was dried with stirring, and kept in an oven overnight at $80^{\circ} \mathrm{C}$. The dried powders were calcined at $750^{\circ} \mathrm{C}$ for $5 \mathrm{~h}$. This calcined sample was ground to a fine powder and pressed into pellet. The pellets were calcined at $790^{\circ} \mathrm{C}$ for $3 \mathrm{~h}$ and crushed. The $\mathrm{NaCo}_{2} \mathrm{O}_{4}$ powders were obtained and used to make a $\mathrm{NaCo}_{2} \mathrm{O}_{4}$ disk for the test of determination of a charge carrier. The $\mathrm{NaCo}_{2} \mathrm{O}_{4}$ powder was pressed into a disk with 20 $\mathrm{mm}$ diameter and $1 \mathrm{~mm}$ thickness. The disk was sintered at $900^{\circ} \mathrm{C}$ for $32 \mathrm{~h}$. 
$\mathrm{LiCoO}_{2}$ was prepared by a standard solid state reaction method from stoichiometric amounts of commercial oxide and carbonate. $\mathrm{Li}_{2} \mathrm{CO}_{3}$ and $\mathrm{Co}_{3} \mathrm{O}_{4}$ (purchased from Wako Pure Chemical Industry, Ltd.) powders were milled by mortar and pestle for $10 \mathrm{~h}$. The milled powders were then calcined at $900^{\circ} \mathrm{C}$ for $3 \mathrm{~h}$. The $\mathrm{LiCoO}_{2}$ powders were obtained and used to make a $\mathrm{LiCoO}_{2}$ disk for the test of determination of charge carrier. The $\mathrm{LiCoO}_{2}$ powder was pressed into a disk with $20 \mathrm{~mm}$ diameter and 1 $\mathrm{mm}$ thickness. The disk was sintered at $900^{\circ} \mathrm{C}$ for $10 \mathrm{~h}$.

\section{Water transport measurement apparatus}

An apparatus was made to measure the transport of water through membranes during the electrolysis of an aqueous solution of an electrolyte $\left(\mathrm{H}_{2} \mathrm{SO}_{4}\right.$ with $\mathrm{pH} 2.1$ and 5.1, and $\mathrm{NaOH}$ with $\mathrm{pH}$ 11.9) across membranes. ${ }^{5}$ A Nafion NRE-212 membrane, an AEM (provided by Tokuyama Co. Ltd.), $\mathrm{NaCo}_{2} \mathrm{O}_{4}$ and $\mathrm{LiCoO}_{2}$ were immersed in the aqueous solution, as shown in Fig. 1. An electric current was passed between two $\mathrm{Pt}$ electrodes through the membrane, and changes in the volumes of the aqueous solution at the anode and cathode were measured by capillary tubes.

During $\mathrm{OH}^{-}$conduction, the following reactions occurred

Cathode $\quad \mathrm{H}_{2} \mathrm{O}+\mathrm{e}^{-} \rightarrow 1 / 2 \mathrm{H}_{2}(\mathrm{~g})+\mathrm{OH}^{-}$

Anode $\quad \mathrm{OH}^{-} \rightarrow 1 / 2 \mathrm{H}_{2} \mathrm{O}+1 / 4 \mathrm{O}_{2}(\mathrm{~g})+\mathrm{e}^{-}$

When a potential was applied across the membrane, the water moved with the anions from the cathode to the anode. Each $\mathrm{OH}^{-}$ion was accompanied by $n$ molecules of $\mathrm{H}_{2} \mathrm{O}$. The ratio of the decrease in $\mathrm{H}_{2} \mathrm{O}$ at the cathode to the increase in $\mathrm{H}_{2} \mathrm{O}$ at the anode was $(1$ $+n) /(1+n)(\approx 1$ when $n>>1)$.

During $\mathrm{H}^{+}$conduction, the following reactions occurred

Anode $\quad 1 / 2 \mathrm{H}_{2} \mathrm{O} \rightarrow 1 / 4 \mathrm{O}_{2}(\mathrm{~g})+\mathrm{e}^{-}+\mathrm{H}^{+}$

Cathode $\quad \mathrm{H}^{+}+\mathrm{e}^{-} \rightarrow 1 / 2 \mathrm{H}_{2}(\mathrm{~g})$

When a potential was applied across the membrane, the water moved with the cations from the anode to the cathode. Each $\mathrm{H}^{+}$ion was accompanied by $n$ molecules of $\mathrm{H}_{2} \mathrm{O}$. The ratio of the decrease in $\mathrm{H}_{2} \mathrm{O}$ at the anode to the increase in $\mathrm{H}_{2} \mathrm{O}$ at the cathode was $(1 / 2+n) / n(\approx 1$ when $n>>1)$. Thus, we could determine the number of water molecules $n$ per conduction of one ion in membranes by observing the changes in the volumes of the aqueous solutions on both sides of the cell.

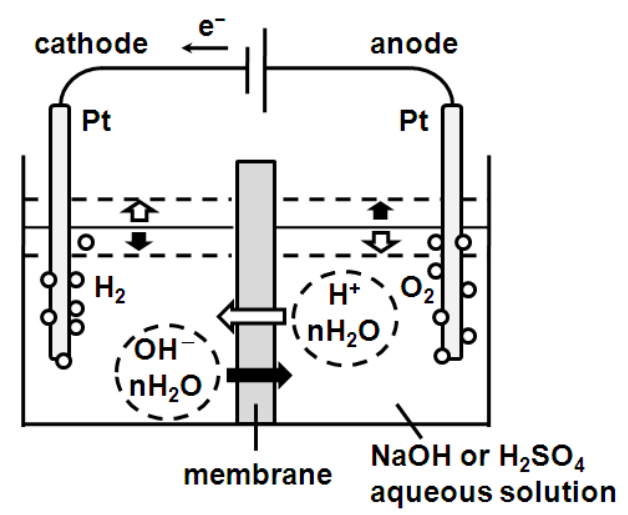

Figure 1. Principle of measurements of water-transport numbers. 


\section{Results and Discussion}

XRD patterns of prepared samples are shown in Fig.2. Because there were no diffraction peaks attributed to impurity, $\mathrm{NaCo}_{2} \mathrm{O}_{4}$ and $\mathrm{LiCoO}_{2}$ were obtained.

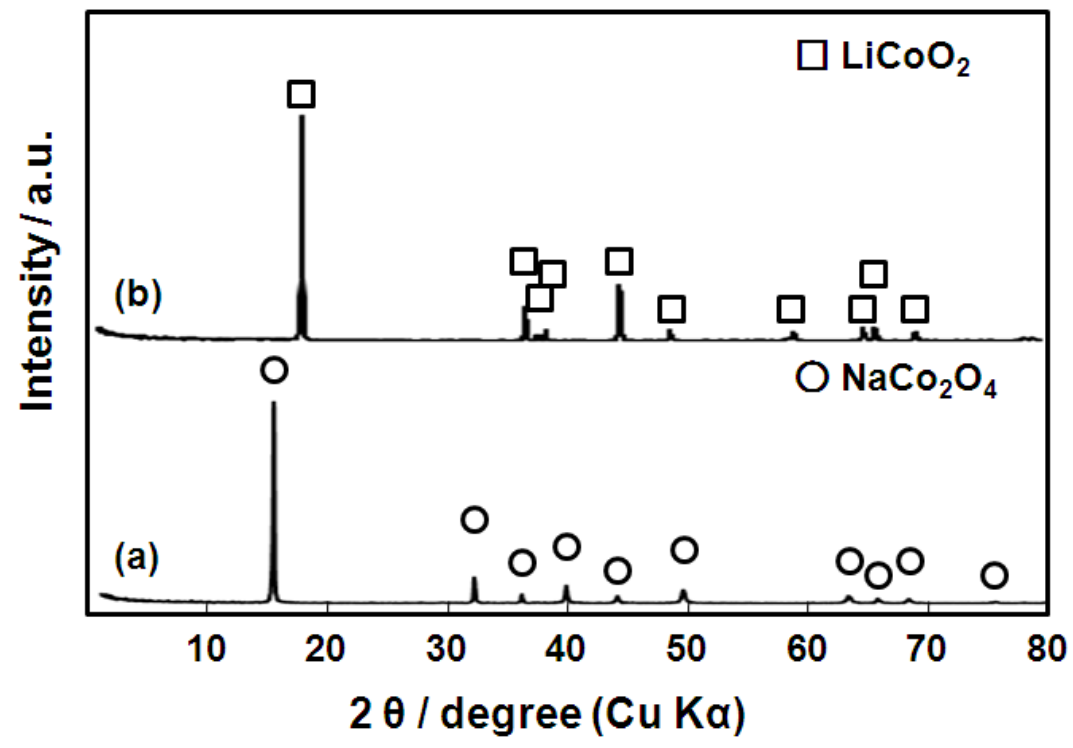

Figure 2. XRD patterns of (a) $\mathrm{NaCo}_{2} \mathrm{O}_{4}$ and (b) $\mathrm{LiCoO}_{2}$.

Figure 3 shows the results of water transport measurements using $\mathrm{Al}_{2} \mathrm{O}_{3}$. In $\mathrm{NaOH}$, the amount of water increased at the cathode and decreased at the anode. This result indicates that the charge carrier is cation in $\mathrm{Al}_{2} \mathrm{O}_{3}$ under alkaline conduction. At the same time, in $\mathrm{H}_{2} \mathrm{SO}_{4}$, the amount of water increased at the anode and decreased at the cathode. This result indicates that the charge carrier is anion in $\mathrm{Al}_{2} \mathrm{O}_{3}$ under acidic conduction. Generally, when $\mathrm{pH}$ value is lower than isoelectric point, the charge carrier tends to be cation because the surface is negatively charged. In contrast, when $\mathrm{pH}$ value is higher than isoelectric point, the charge carrier tends to be anion because the surface is positively charged. The isoelectric point of $\mathrm{Al}_{2} \mathrm{O}_{3}$ is $7.0 \sim 9.0$. Thus the results for $\mathrm{Al}_{2} \mathrm{O}_{3}$ are reasonable.
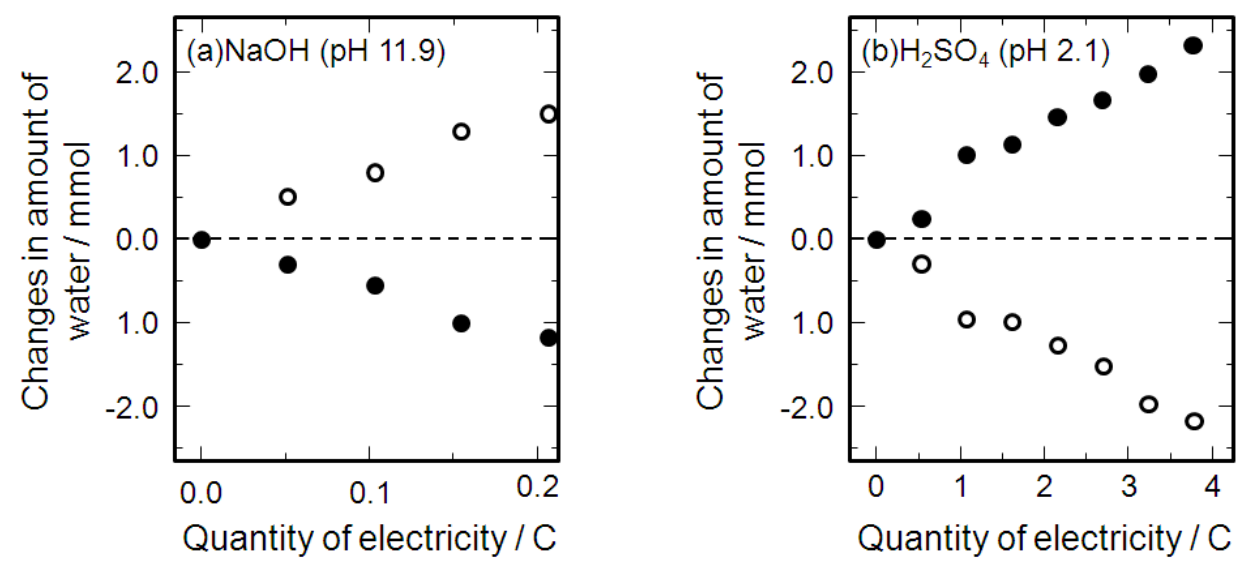

Figure 3. Changes in amount of water at the anode and cathode sides during electrolysis and electro-osmosis through $\mathrm{Al}_{2} \mathrm{O}_{3}$. (a) Results with $\mathrm{NaOH}$ at $\mathrm{pH}$ 11.9. (b) Results with $\mathrm{H}_{2} \mathrm{SO}_{4}$ at $\mathrm{pH}$ 2.1. Open and closed circles are results at the cathode and the anode, respectively. 
Table I shows the charge carrier in various solid electrolytes under alkaline and acidic conditions. For Nafion, the charge carrier is always cation, while for AEM, the charge carrier is always anion in both solutions. Therefore, Nafion and AEM have been used as fuel cell electrolytes.

In the case of $\mathrm{NaCo}_{2} \mathrm{O}_{4}$, the charge carrier is anion under alkaline condition. Furthermore, $n$ of water molecule is smaller than organic membrane. $\mathrm{NaCo}_{2} \mathrm{O}_{4}$ is expected to apply for AFC electrolyte as a new type electrolyte. In the case of $\mathrm{LiCoO}_{2}$, however, the charge carrier is cation even though $\mathrm{LiCoO}_{2}$ has a similar layered structure to $\mathrm{NaCo}_{2} \mathrm{O}_{4}$. It is suggested that the $\mathrm{Co}$ valence was changed by substituting $\mathrm{Na}$ with $\mathrm{Li}$, resulting in the change in conductor. The difference of the charge carriers between these two layered oxides will be studied in the future.

TABLE I. Charge carriers in various solids under alkaline and acidic conditions.

\begin{tabular}{ccc}
\hline & \multicolumn{2}{c}{ Charge carrier } \\
\cline { 2 - 3 } & Alkaline condition & Acidic Condition \\
\hline $\mathrm{Nafion}$ & cation & $\mathrm{H}^{+}$ \\
$\mathrm{AEM}$ & $\mathrm{OH}^{-}$ & anion \\
$\mathrm{NaCo}_{2} \mathrm{O}_{4}$ & $\mathrm{OH}^{-}$ & anion \\
$\mathrm{LiCoO}_{2}$ & cation & cation \\
\hline
\end{tabular}

\section{Conclusions}

Water transport during ion conduction in the membranes was measured to determine the charge carrier and to seek suitable electrolytes for AFC. It was revealed that the anion conduction occurred in $\mathrm{NaCo}_{2} \mathrm{O}_{4}$ even under alkaline condition. We thought that this oxide could be used for AFC electrolyte.

\section{Acknowledgments}

This study was supported by Strategic Development of PEFC Technologies for Practical Application Grant Program from New Energy and Industrial Technology Development Organization (NEDO) of Japan.

\section{References}

1. J. R. Varcoe and R. C. T. Slade, Fuel Cells, 5, 187 (2005).

2. J. S. Park, S. H. Park, S. D. Yim, Y. G. Yoon, W. Y. Lee and C. S. Kim, J.Power Source, 178, 620 (2008).

3. E. Agel, J. Bouet, J. F. Fauvarque, J. Power Source, 101, 267 (2001).

4. C. Tamain, S. D. Poynton, R. C. T. Slade, B. Bryony and J. R. Varcoe, J. Phys. Chem. C, 111, 18423 (2007).

5. T. Yamanaka, T. Takeguchi, H. Takahashi and W. Ueda, J. Electrochem.Soc., 156, B831 (2009). 